\title{
THE EVOLUTION OF THE FEDERAL TAX SYSTEM
}

\author{
Ror Brouga*
}

The evolution of the federal tax system has been from small volume of revenues to large volume, from a simple structure to a highly complicated and diverse structure, from almost complete reliance on indirect taxes to heavy reliance on progressive direct taxes.

Over the three-fourths of a century of national life prior to the Civil War the tariff on imports was the overwhelmingly important source of federal tax revenue and during two-thirds of that period no other taxes were in effect. Basic developments in the federal tas system have come for the most part in three major waves which occurred during and after the Civil War, the World War and the recent depression. Each wave was characterized by a great extension and muliplication of revenue sources, followed (at least in the first and second waves) by a contraction and abandonment of sources, with a net long-term result of expansion and diversifcation of the system. The Civil War period added to the tariff, internal revenue taxes on liquor and tobacco as permanent revenue sources. The World War period enlarged the income tax, which had just been introduced, from a minor position to that of the major source of federal revenue, and added the estate tax. The outcome of the latest major tax wave, that of the recent depression period, is still uncertain, but there is little doubt that the permanent effects on the tax system will be of major character. ${ }^{1}$

- Ph.D., 1929, University of Wisconsin. Dircctor of Tax Research, United States Treasury Department, since 1938. Chief Statistician, Wisconsin Tax Commission, 1927-1932; Asscciate Profeseor of Economies, Graduate School of Public Administration, University of Cincinnat, 1932-r938. Author and joint author of various articles and works in the field of taxation.

2 Other waves of taxes which left no apparent permanent changes in the tax structure occurred during the first decade of national life, the War of 1812 , and the Spanish-Imerican War, respectively.

The first Act of Congress in $17^{\circ} 9$ imposed 2 tariff for revenue and protection. The revenue was insuffcient, and during the nexi few years taxes were imposed on the manufacture of whiskey, snuff and su 525, legal documents and carriages, and in 1798 a single payment direct eax levy was imposed on houses, slaves and lands. Colloctions from the various internal levies and the direct tax were relatively small, exceeding $: 5 \%$ of the collections from the tariff in only one year. All internal taxes were repealed in 1802 or shortly thereafter.

Opposition to internal taxation continued to be so strong that despite the requirements of the War of 1812 , no new taxation was provided until the summer of 1813 when taxes were imposed on liquorn, sugar refining, carriages, auctions and financial instruments, and a broad list of manufacturers' sales, and a single payment direct tax imposed on houses, slayes and land. T2x rates were increased in 1814 2nd in 1815 the internal revenue, including the direct tax, nearly equalled the reduced customs receipts of that year. Following a very high customs yield in the next year, after the end of the war, the war taxes were practically all repealed.

From 2817 until the Civil $W_{a r}$ the tariff was practically the sole source of tax revenuc, adjustments being made in the rates from time to time to meet the demands for revenue and protection. Revenues 
Because of the long period with no internal taxation, it is perhaps not surprising that Congress showed some reluctance about passing such taxes when the Civil War started in 186r. In August 186r, a single payment direct tax on property and an income tax were imposed. A new income law was passed in 1862 and taxes were also placed on many other sources including spirits, tobacco, gross sales at a variety of specific and ad valorem rates, inheritances, legal documents, checks, occupations and professions, and possession of certain articles of luxury. Rates of the income tax, inheritance tax and most of the other taxes were increased in 1864. The peak of war revenues was reached in 1866 , with customs and internal revenues totaling approximately a half billion dollars, of which the income tax furnished about $15 \% \%^{2}$

In 1866 the manufacturers' excises were generally reduced $20 \%$ and some were repealed; in 1867 others were repealed; in 1870 the gross receipts, sales, and inheritance taxes were repealed, while the income tax was reduced and set to expire in 1872 . Taxes on tobacco and liquor were not repealed but remained as permanent elements in the tax system, together with the tariff, which was imposed at high and generally increasing protective rates and continued to be the dominant revenue source.

The tax system was at this time, as before the Civil War, made up of regressive taxes. In conjunction with the agrarian movement of the last quarter of the century, sentiment developed for the imposition of an income tax, not because of a need for new revenue, but to place heavier tax burdens on the wealthy. An income tax act was passed in 1894 , but was declared unconstitutional in 1895 as being a direct tax and thus requiring apportionment among the states according to population. Toward the latter part of the first decade of the 1900's the movement for the income tax regained strength and in 1909 a corporation excise tax was imposed and an amendment submitted to the states to permit imposition of an income tax without apportionment. The amendment, the Sixteenth, was adopted by a sufficient number of states in February I913, and that year a personal income tax law was passed.

At the opening of the European War in 1914, the tax system of the United States consisted of the tariff, taxes on distilled spirits and fermented liquors, tobacco and tobacco products, individual and corporation incomes, playing cards and bank note circulation; and a group of taxes on oleomargarine, adulterated and processed butter, filled cheese, mixed flour, state bank notes, and white phosphorus matches, which were imposed for their regulatory effects rather than for revenue. The relative im-

were in excess of requirements in the 1830 's, leading to a distribution to the States just before the disastrous crisis of 1837 .

After the Civil War period the tariff, together with liquor and tobacco taxes, supplied revenues adequate to meet expenditures. Indeed, total revenues were again embarrassingly large in the 1880's, perhaps for the last time.

The Spanish-American War of 5898 caused only temporary additions to the tax system. Various kinds of taxes were passed, including excises, an import duty on tea and a tax on the inberitance of personal property graduated according to the size of the personal property estate. These taxes did not remain in operation long, being entirely abolished by 1902.

2 See Schultz and Caine, Financiar Development in the United States (1937) passim. This work was relied on extensively for the period prior to 1917 . 
portance of the various taxes is seen in the following table of revenues in the fiscal year rgr4:

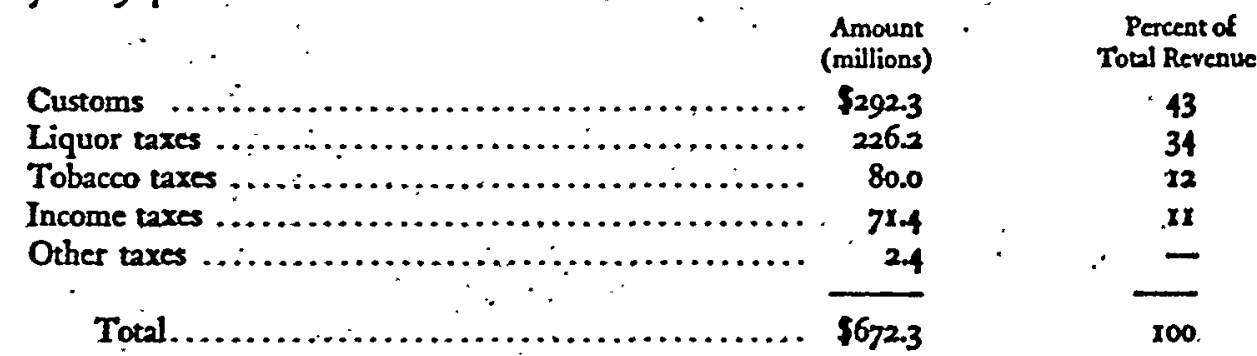

The series of revenue-raising acts of the World War period began in 1914 with imposition of a group of stamp taxes and other excises, including occupational taxes on tobacco manufacturers. The Act of 1916 roughly doubled the income tax rates, imposed an estate tax, capital stock tax, and a tax on the net profits of munition manufacturers, and repealed or revised most of the 1914 excises. The act passed in March 1917 increased the estate tax rates and imposed an excess-profits tax on corporations and partnerships. The first real war revenue act was passed in October 1917. It reduced the exemptions of the individual income tax and greatly increased the rates, imposed an excess-profits tax on individuals and raised the rates on corporations and partnerships, again increased the estate tax rates, substantially increased the tobacco taxes. and very heavily increased the liquor taxes, and imposed a long list of excise taxes on various kinds of transactions. The peak rates of the war period were reached under the Revenue Act of 1918 , passed early in 1919 , which again increased the income tax rates, limited the excess-profits tax to corporations but added a heavy war-profits tax, and again increased tobacco and liquor taxes and added new excises, including retail sales taxes on a group of semi-luxury items.

The peak of the war tax revenues was reached in 1920 when the various major groups of taxes produced the amounts indicated in the following table:

\begin{tabular}{|c|c|c|}
\hline$\therefore \quad: \quad:$ & $\begin{array}{c}\text { Amount } \\
\text { (millions) }\end{array}$ & $\begin{array}{l}\text { Percent of } \\
\text { Total Revenue }\end{array}$ \\
\hline 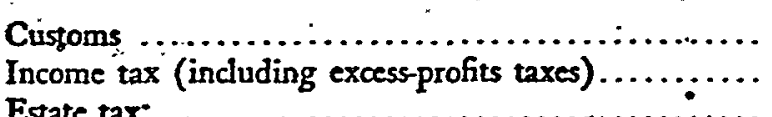 & $\begin{array}{r}322.9 \\
3,956.9\end{array}$ & $\begin{array}{r}6 \\
69\end{array}$ \\
\hline 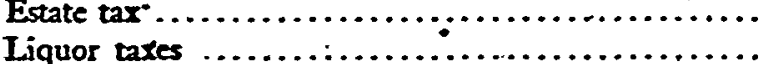 & $\begin{array}{l}103.6 \\
139.9\end{array}$ & $\begin{array}{l}2 . \\
2\end{array}$ \\
\hline Tobacco tares $\ldots \ldots \ldots \ldots \ldots, \ldots \ldots \ldots \ldots \ldots \ldots \ldots \ldots$ & 295.8 & 5 \\
\hline Other taxes ... & 911.4 & " 16 \\
\hline $\mathrm{ml}$ & 30.5 & 100 \\
\hline
\end{tabular}

The liquor taxes had produced much more heavily in the previous year ( $\$ 483.1$ millions) but prohibition cut down the revenues for 1920 . It is interesting to note that customs produced little more in 1920 than in 1914 while income and excess-profits taxes reached nearly four billion dollars, or more than two thirds of the total revenues.

The tax reductions following the War were effected by the Revenue Acts of $\mathbf{x g 2 1}$, 
1924 and 1926 , with a further minor reduction in 1928. The excess-profits taxes, capital stock tax, and most of the excises were repealed during this period. Under the 1926 Act the offset of state death taxes against the federal estate tax, which, under the 1924 Act, was allowed up to $25 \%$ of the latter, was raised to $80 \%$, thus making the federal tax little more than a means of protecting states in the imposition of death taxes against the competition of other states which chose not to impose such taxes. Income tax rates on individuals were lowered and exemptions raised, the maximum combined normal and surtax rates under the 1926 Act being 25\%. Despite this decrease, the income tax was the outstanding source of revenue during the 1920 's, its maximum significance appearing in the following figures for 1930:

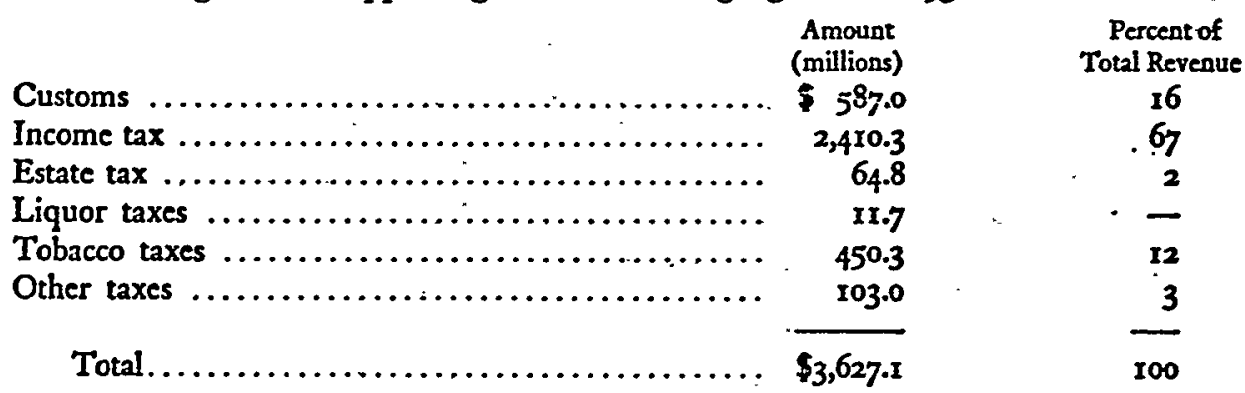

Tax revenues fell off rapidly after 1930 , in part due to the sensitivity of the income tax to declining business. Only $\$ 1,885$ millions was collected in fiscal 1932: The imposition of increased taxes to restore the depression-reduced revenues did not begin until that year but thereafter important revenue legislation was passed in every year through 1939. The Acts of 1932 through 1937 strengthened the power of the revenue system. The Acts of 1938 and 1939 were designed to maintain the revenue yield while changing provisions that were deemed to need adjustment. It may be useful to trace the development of some of the more important types of taxes during this period.

The individual income tax in 1932 was greatly strengthened as a revenue producer by reducing personal exemptions and substancially increasing both normal and surtax rates. Under the last pre-depression revenue act, that of 1928 , personal exemptions for single persons were $\$ 1,500$, for married persons $\$ 3,500$, with an additional credit of $\$ 400$ for each dependent. Rates ranged from $\mathrm{r} 1 / 2 \%$ to a maximum combined normal and surtax rate of $25 \%$ on income over $\$ 100,000$. The 1932 Act reduced exemptions to $\$ 1,000$ and $\$ 2,500$ respectively, and increased rates to range from $4 \%$ to a maximum combined rate of $63 \%$ on income over $\$ 1,000,000$. In 1934 income tax rates were again increased although most of the change was a shift from the normal rate to the surtax. In 1935 income surtaxes were increased to begin the next year. The increases applied to incomes above $\$ 50,000$ and the maximum combined normal tax and surtax was $79 \%$ on income over $\$ 5,000,000$.

Corporation income taxes were likewise increased during this period. Under the I928 Act the corporate rate was $12 \%$ with an exemption of $\$ 3,000$ allowed to each corporation. In 1932 the exemption was abolished and the rate increased to $133 / 4 \%$. 
In the 1935 Act the tax was given a graduated rate scale ranging from $12 \frac{1}{2} \%$ on the first $\$ 2,000$ of net income to $15 \%$ of incomes above $\$ 40,000$, but the rates never went into operation, being replaced by provisions of the Revenue Act of 1936 before they became effective. The immediate incident which gave rise to the $193^{6}$ Act was the decision of the Supreme Court invalidating the agricultural processing.taxes, thus eliminating a substantial volume of revenue. The new law was a compromise between different points of view and provided for a graduated tax on corporations ranging from $8 \%$ on the first $\$ 2,000$ of net income to $15 \%$ on net income above $\$ 40,000$. A surtax on undistributed profits was imposed, the tax being graduated from $\% \%$ of an amount of undistributed profits not in excess of $10 \%$ of adjusted net income to $27 \%$ on undistributed profits in excess of $60 \%$ of adjusted net income, with some reduction for corporations with incomes of less than \$50,000. The exemption from personal normal income tax, previously granted for corporate dividends, was repealed In $193^{8}$ the undistributed profits tax was largely reduced and its method of computation changed so that it did not apply to corporations with less than $\$ 25,000$ of net income and amounted to only $21 / 2 \%$ of retained earnings of corporations with more than that amount of net income. The rates thus imposed were to expire at the end of $1939.9^{-}$The Revenue Act of 1939 continued the rates on small corporations, but substituted a flat rate of $18 \%$ for the previous tax on corporations with over $\$ 25,000$ net income.

Numerous other changes in the income tax laws were made during the period 1932-1939, many of them restricting deductions or otherwise expanding the tax base. An earned income credit which had been allowed to individuals was abolished in 1932 but restored in restricted and modified form in 1934. The carry-over of business losses was reduced from two years to one year in 1932 and eliminated in 1933 , being again restored in 1939. The income of corporations filing consolidated returns in 1932 was subjected to an additional rate of $3 / 4 \%$, this rate rising later to as high as $2 \%$ before it was eliminated in 1936, while in 1934 consolidated returns were abolished except for railroad corporations. In the 1935 Act the corporate tax base was extended to include $3.0 \%$ of intercorporate dividends beginning in 1936 and this was increased bafore becoming effective to $15 \%$ by the 1936 Act. In 1932 and 1933 and especially in the I934 Act, capital gains of individuals were given a much less favor. abie position than they had held formerly when gains on assets held over two years were subjected to a maximum rate of $121 / 2 \%$, but the favorable position was largely restored in 1938 when a $15 \%$ effective maximum rate was provided. Deduction of capital losses from ordinary income was greatly restricted in 1934 for both individuais and corporations, but the previous treatment was largely restored in $193^{9}$ and 1939. A tax was placed on personal holding companies in 1934. Further legislation to prevent the use of such holding companies and other methods of avoiding the personal surtaxes was provided in the Revenue Act of 1937 in which new rules of taxability .were provided with respect to holding companies, trusts, etc. In 1939 fol-

'U. S. v. Butle, 297 U. S. I (1936). 
lowing favorable Supreme Court decisions the salaries of state and local officers were made subject to federal income tax and the federal government consented to state taxation of federal salaries. An effort on the part of the President and the Treasury Department to secure similar taxability of the interest on future issues of governmental securities was not acted on in 1939 .

In 1933 a capital stock tax was imposed. Unlike the tax of the World War period, the tax was based on a declared value of capital stock of corporations, the amount declared being at the option of the taxpayer. To prevent the declaration of low capital stock values, a so-called excess-profits tax was imposed on profits. in excess of $121 / 2 \%$ of the declared value, the percentage and tax rates being changed in later legislation. Succeeding revenue acts permitted several redeclarations of value and the 1938 Act permitted a redeclaration every three years, while the 1939 Act permitted additional upward redeclarations in 1939 and 1940.

The payroll taxes passed in 1935 as part of the social security program comprised a new element in the federal tax system. Payroll taxes to finance old-age insurance were imposed on all employers and employees except in certain specified groups, notably agriculture, religious and charitable organizations and governments. A similar tax on employers of eight or more persons was imposed at rates beginning at $1 \%$ and rising to $3 \%$ in 1938 . Against this tax was allowed a credit of contributions paid to state unemployment insurance systems up to $90 \%$ of the federal tax, which was thus intended primarily to encourage the adoption of state unemployment compensation systems. The payroll taxes for old-age insurance were at rates of $1 \%$ each on employer and employee, with rates to increase at three-year intervals, totalling $3 \%$ each, beginning in 1949 . In 1939 the step-up of $1 / 2 \%$ each, scheduled to take place in r 940 , was cancelled.

In 1932 the federal estate tax rates were increased from a range of $1 \%$ to $20 \%$ to a range of $1 \%$ to $45 \%$, the higher rates in both cases applying to amounts of estates in excess of $\$ 10,000,000$. The credit for state death taxes was retained but was not extended to the rate increases so that all the new revenue went to the federal government. A gift tax was imposed to reduce avoidance of the estate tax through gifts inter vivos. Estate (and gift) tax rates were increased again in 1934 and still again in 1935 when a maximum bracket rate of $70 \%$ was imposed on amounts of net estates in excess of $\$ 50,000,000$, while the specific exemption was reduced to $\$ 40,000$ from its previous level of $\$ 50,000$. An effort in 1938 to adjust the credit for state taxes and apply it to the whole federal tax was resisted by representatives of states and was not passed.

Liquor taxation was continued throughout the prohibition period, but its employment as a significant revenue source was resumed in 1933 when Congress determined that fermented liquors with an alcoholic content of not more than $3.2 \%$ were not in violation of the Eighteenth Amendment and imposed excise taxes on such beverages and occupational taxes on producers and dealers. The Eighteenth Amendment was repealed in December 1933 and in 1934 a tax on distilled liquors was imposed at the 
rate of $\$ 2.00$ a gallon and changes were made in the taxation of fermented beverages. A minor increase in the tax on distilled liquors was made in 1939.

Tobacco taxes were not increased during the period.

A small number of stamp and other excise taxes were in effect prior to 1932. In that year the rates of some of these were increased while manufacturers sales taxes on a long list of products and taxes on checks, telephone and telegraph messages and other transactions were imposed. A federal tax was placed on gasoline, which was also being taxed by every state. In 1934 a number of minor excises were repealed and the gasoline tax was reduced, while a tax was imposed on the profit from the sale of silver bullion, this tax being a feature of the law providing for silver purchases by the Treasury. The $193^{8}$ law also repealed a few of the smaller excises and reduced the rates on some others. In general, however, the excise taxes at the beginning of $194^{\circ}$ were as they were originally imposed in 1932.

A new form of manufacturers' excise was imposed under the Agricultural Adjustment Act of 1933 in the so-called agricultural processing taxes, which extended to most of the basic agricultural products and to some competing commaditice. The rates of these taxes were to be determined by the Secretary of Agriculture and the proceeds used for farm benefits and crop control. The processing taxes were declared unconstitutional early in 1936 , primarily on the ground that they were an inseparable element in an agricultural control program beyond the power of Congress to impose. The decision ${ }^{5}$ left the status of process taxpayers in a somewhat confused state since some had paid the voided taxes while others had not. In order that procersors who had shifted the tax to others should not gain from its invalidation, the I936 Act imposed a tax on "unjust enrichment." The tax was $80 \%$ of the net income from the sale of articles with respect to which a federal excise tax was imposed and shifted to others but not paid to the government. The measure of the tax was the net income but not to exceed the amount of the shifted tax. A processing tax was imposed on sugar in 1937.

A highly protective tariff was passed in 1930 and no new tariffs were imposed thereafter through 1939. However, additional restriction of imports was provided in $193^{2}$ by imposing excise taxes on the import of coal, copper, petroleum products and lumber. Other import excises together with processing taxes on certain.imported vegetable oils were imposed in 1934 . The reciprocal trade treaties, since r934, have ameliorated tariffs and import excises in some respects. .

The tax collections of the fiscal year 1939 are shown in the following table:

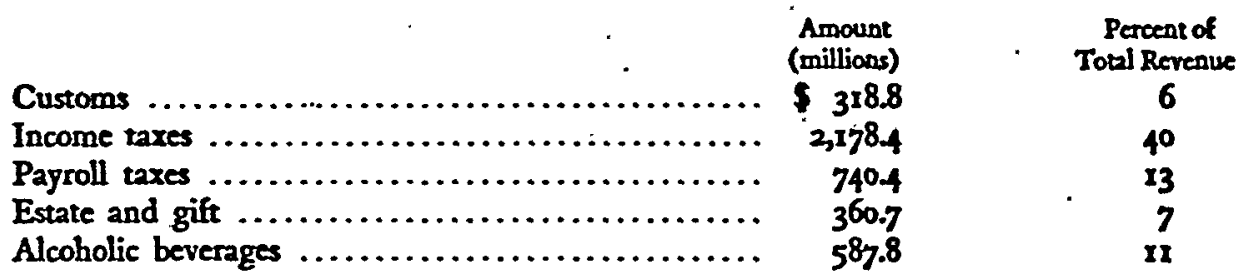

\footnotetext{
- Prior to repeal, the tax on distilled spirits used for non-beverage purposes was \$1.10 per gallon, for beverage purposes, $\$ 6.40$. "Supre note 3 .
} 


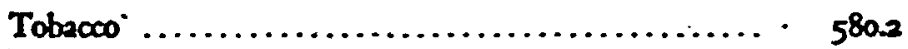

Manufacturers' excises ..................... $396-9$

Oher taxes $\ldots \ldots \ldots \ldots \ldots \ldots \ldots \ldots \ldots \ldots \ldots \ldots, \quad 337.2$

Total ............................. $\frac{3372}{\$ 5,500.4}$

During the previous year, fiscal 1938, the income tax colloctions totaled $\$ 2,603$ millions, which exceeded the 1930 figure and was also higher than the war-time peak income tax collections (exclusive of excess- and war-profits taxes).

Several points may be worthy of note in commenting on tax developments. The direct taxes for which special provision was made in the Constitution whereby they were to be apportioned for collection among the states according to population were used only three times, in 1798 , in $181_{3}$ and 1814 , and in 1861 . The first two taxes were on lands, houses and slaves, the last on general property. Under the 1861 tax the states were permitted to assume their quotas and pay direct, thus eliminating the necessity of federal administration. The tax collections were very slow in coming in and in $189:$ all sums collected or credited to states were distributed back to them.

While taxes have in the main been imposed for revenue purposes, some use has been made of taxation for regulatory purposes. The protective tarif, of course, is the outstanding example. A prohibitory tax on state barik notes was imposed in s865 and is still in effect. A ro-cent a pound tax was placed on colored oleomargarine in Ig02. A tax was placed on the use of white phosphorus in the manufacture of matches in 1912. The taxation of profits from products of child labor in interstate trade was held unconstitutional as was a recent tax on producers of bituminous coal not coming under code regulation, but taxes on certain types of transactions, on commodity exchange, on narcotics and on firearms have been upheld.

The growth of the federal tax system has been given direction by many factors. The impelling force for expansion has been the increased need for revenues. Increases in annual expenditures have been on the whole gradual during times of peace, but major wars have resulted not only in heavy costs for fighting but in a permanently expanded level of peace-time expenditures. Thus, the lowest point reached by expenditures after the Civil War was over three times as high as prewar expenditures and the low point after the World War was over four times as high as before the War. Part of the increases were due to price changes, but the operations and functions of government had permanently expanded also. The latest major wave of higher tax rates and additional taxes grew out of the combination of increasing expenditures and declining revenues brought about by the depression.

The greatest influence on the tax system has undoubtedly been changes in industrial and social conditions. Such changes were, of course, largely responsible for the pressure of increased expenditures. They also made available and acceptable sources of taxation which were not practical in earlier years. Examples are the income taxes, the estate and gift taxes and the war-time excess-profits taxes.

In the interaction of these and other forces, accident and personal leadership and rivalries have throughout played important roles in directing the evolution of the tax system. 
The changes in the tax system and its immense expansion in size have brought to the front a new group of tax problems, few of which were in existence thirty years ago. Some of these problems are within the federal tax system while others involve relations between the federal government and the states and localities. The latter type of problems has arisen largely because of the extension of the federal tax system to include many new sources into which state tax systems were at the same time being similarly extended. When the federal government relied on the tariff and the states used the property tax almost exclusively, there was little or no conflict or competition for revenue between them. As has been seen, since 1909 the federal tax system has extended into many new fields, while the states have likewise reached out in all directions open to them. The result is that in numerous cases the federal government and the states are taxing the same base, often to the distress and great inconvenience of the taxpayers. Other problems have grown out of the increasing use of matching grants-in-aid, and the allowance of credits against federal taxes for payments of state taxes which is provided in the estate tax and the payroll tax for unemployment compensation.

The problems within the federal tax system are the subjects of the papers in this symposium and will not be passed in survey here. It is interesting to observe that the problems discussed all concern the newer taxes on incomes and estates imposed during the past thirty years and which constitute the most successful effort to date to adjust tax burdens to the varying abilities and responsibilities of the members of the community to contribute to the support of government. It is an encouraging fact that the problems exist largely because of a public sensitiveness to the desirability of improving the equity and economic effects of the tax system. 